108

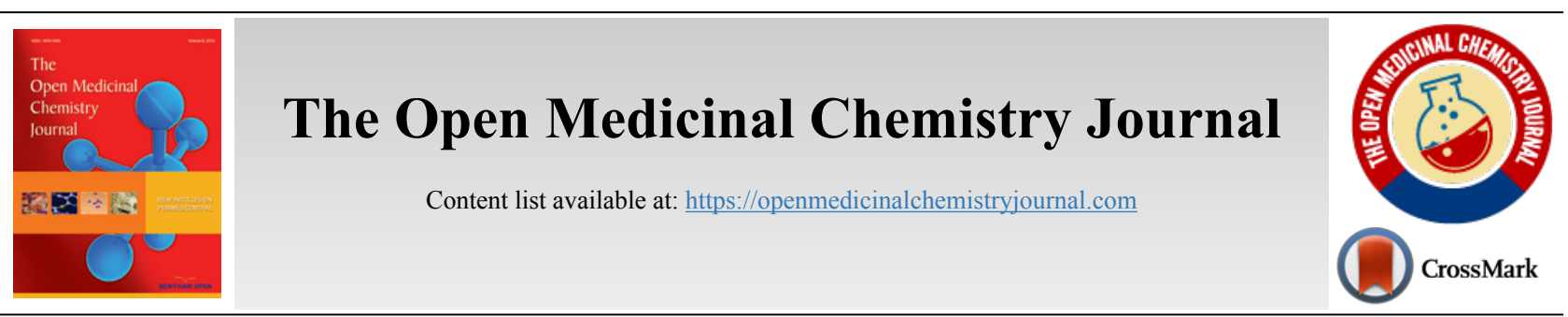

REVIEW ARTICLE

\title{
Synthesis of Medicinally Important Quinazolines and Their Derivatives: A Review
}

\author{
Sulochana Sharma ${ }^{1}$, Kailash Sharma ${ }^{2}$, Sakshi Pathak ${ }^{3}$, Mahendra Kumar ${ }^{3}$ and Praveen Kumar Sharma,", \\ ${ }^{\prime}$ Department of Chemistry, S.B.R.M. Govt. College, Nagaur, Rajasthan, India \\ ${ }^{2}$ Department of Chemistry, Kartik College, Nagaur, Rajasthan, India \\ ${ }^{3}$ Department of Chemistry, University of Rajasthan, Jaipur, India \\ ${ }^{4}$ School of Chemical Engineering and Physical Science, Lovely Professional University, Phagwara, Punjab, India
}

\begin{abstract}
:
The study of biodynamic heterosystems has proved to be the most attractive and useful for the development of potential drugs with superior properties and works effectively for the treatment of a variety of diseases, including pandemic ones. Out of the thousand biodynamic heterosystems, the quinazoline heterosystem is one that exhibits wide-ranging biological and pharmacological properties. Synthesis of potential medicinal material is comparatively challenging and needed enough time for clinical trials, testing, permissions for concerned authorities, production and supply. Therefore, researchers usually focused on novel methods incorporated with a high yield of previously approved chemical compounds. This present review article has focused on the synthesis of medicinally important quinazolines and their derivatives, which produce reaction products in less time with high yields, including more attention with eco-friendly green synthesis approaches incorporating multicomponent reactions (MCR), ionic liquids and microwave irradiations.
\end{abstract}

Keywords: Ionic Liquids, Multicomponent reactions (MCRs), Quinazolines, Quinazolinones, Antimicrobial agents, Green synthesis, benzothiazoloquinazolines.

\begin{tabular}{|l|l|l|l|}
\hline Article History & Received: June 24, 2020 & Revised: September 15, 2020 & Accepted: September 20, 2020 \\
\hline
\end{tabular}

\section{INTRODUCTION}

Human society in the present time experiences a variety of problems related to health, and few of them are in the category of a pandemic. Pandemic problems generally arise in a very short period of time and cause an unexpected adverse effect on human development. At this stage, researcher/chemist provides instant solutions. Researchers mainly adopt two approaches: either synthesis of potential medicinal material against said deceases or production of existing chemical material by adopting new methods, which replace time-consuming complex existing methods to avoid the shortage and make available. Synthesis of potential medicinal material is comparatively challenging and requires enough time for clinical trials, testing, permissions for concerned authorities, production and supply. Therefore, researchers usually focused on other synthetic methods of previously approved chemical compounds. For more than a century, in the first stage, chemists mainly found solutions to targeted chemicals in

\footnotetext{
* Address correspondence to this author at Department of Chemistry, Lovely Professional University, Phagwara, Punjab, India-144411; Tel: +919023591664; E-mail: pk_pandit1982@yahoo.com
}

heterocyclic compounds. In this sequence, the synthesis of heterocyclic compounds has more concerns with heterocyclic chemistry along with pharmaceutical/medicinal chemistry. The formulation of biodynamic heterosystems by fusion has been verified to be a very smart and convenient way for scheming novel molecular structure of prospective medicinal material with variable pharmacological activities [1 - 28]. Heterocyclic compounds synthesis with fused hetero-systems includes, in many cases, a multistep synthetic approach, which needs a great number of synthetic procedures together with extraction and purification of every single step. Synthetic methodologies with multistep, consequently, headed to the synthetic ineffectiveness along with the production of huge amounts of waste. Hence, in view of chemistry with a sustainable approach [29], the development of new synthetic ways which provides selective admittance to clarified scaffolds combined with a molecular variety [30] and compatibility with the environment [31] has always been a countless competition for chemical and medicinal research.

Due to their in-operation effortlessness and capability to produce only one product from more than two components in a single synthetic process, multiple bond-forming efficiencies, 
and high atom economy [32], multicomponent reactions (MCRs) have arisen as the most effective synthetic approach [33]. In recent times, multicomponent reactions (MCRs) have been involved in medicinal-pharmaceutical research and appeared as synthetically most important reactions for the preparation of heterocyclic compounds, which can be used as potential drugs. The MCRs, including Biginelli, Hantzsch and Ugi condensation reactions, as well as a number of newly discovered MCRs, have been used for the synthesis of heterocycles(fused) with the introduction of structural diversity and molecular diversity.

Environmentally benign and cost-effective catalytic systems, used as important materials in the main themes of modern synthetic chemistry, were prepared by the use of the most effective principles of green chemistry. In this point of view, due to avoidable vapor pressure (vp) and non-flammable nature [34], Ionic liquids (ILs) have been used as alternatives to hazardous volatile organic solvents. Therefore, various organic chemists nowadays use ionic liquids (ILs) as catalysts/solvents [35].

In recent years, the use of ionic liquids (ILs) either as solvents or catalysts has shown significant changes in the results of many organic transformations. Ionic liquids (ILs) have shown superiority as solvents with many advantages over traditionally used organic solvents in synthetic organic reactions. It has been reported that the structure of the ionic liquid has an intense effect on the solubility, reactivity and other possible reaction variables. With a sensible grouping of cations and anions, it is promising to adjust the solvent behavior in order to modify the most suitable ionic liquid (IL) for synthetic applications. It has been observed that by the practice of ionic liquids (ILs), the yield of the final product can be optimized only with the minor change of the ions: anions or cations. Moreover, the combination of functional groups can improve their function by increasing most probably stability, suitability and reusability of ILs as compared to the nonfunctionalized equivalents [36].

Brønsted acidic ionic liquids-ILs (combine the advantages of solid acids and mineral acids) have been used as catalysts in many synthetic transformations (acid-catalyzed) and produced significant interest [37]. Bronsted acidic ionic liquids (ILs) and their homogeneous system can be readily separated from the reaction products along with miscible water. Thus, ILs can be used in both homogeneous and heterogeneous catalysis. Functionalized ionic liquids can be readily synthesized so that the ILs have advantages over already exiting conventional catalysts. Important ionic liquids (ILs) can be treated as effective catalysts and can be recovered without any appreciable loss in catalytic activity.

The presence of $\mathrm{SO}_{3} \mathrm{H}$ functional group in ionic liquids improves their solubility in water with superior acidities [38]. Thus, $\mathrm{SO}_{3} \mathrm{H}$ functional group-containing ionic liquids can be used as important acid catalysts in addition to their use as solvents so that the ionic liquids can be used as a green substitute catalyst to the existing conventional acid catalysts, such as $\mathrm{HF}, \mathrm{H}_{2} \mathrm{SO}_{4}, \mathrm{AlCl}_{3}$ etc. in various chemical syntheses [39].

Due to the presence of quinazoline structure as a building block in various natural products and synthetic pharmaceuticals, researchers have attracted their attention towards the synthesis of quinazolines in view of their wideranging biological and therapeutic activities [40] including antibacterial [41], anti-fungal [42], anti-cancer [43 - 46], antiinflammatory [44] and antihypertensive [45] activities. Furthermore, quinazoline derivatives have also been wellrecognized for their use as anticonvulsants [47], sedatives [48], vasodilator [49 - 51], phosphodiesterase inhibitors [52], and fibrinogen receptor antagonists [53].3-Aminoquinazoline-2,4diones (AQDs) have been reported as powerful topoisomerase inhibitors [54].

Quinazoline derivatives have recently been evaluated as calcitonin gene-related peptides $[55,56]$ and vasopressin V3 receptors [57]. Additionally, quinazolinones have also been reported to exhibit anti-proliferative activities and also shown inhibitory effects for thymidylate synthase, such as Doxazosin mesylate $\mathbf{1}$ with quinazolinone structural moiety is an alphablocker and nowadays being used for the treatment of high blood pressure and prostatic hyperplasia (BHP). Quinazoline derivatives 2 can also be used as strong inhibitors of the epidermal growth factor (EGF) receptors of tyrosine kinase (EGFR) routed through a realistic system with the binding of ATP [58] (Fig. 1).<smiles>COc1cc2nc(N3CCN(C(=O)C4COC5C=CC=CC5O4)CC3)nc(N)c2cc1OC</smiles><smiles>[R]c1cc([R])cc(-c2cc3cnc([R])nc3nc2[R])c1</smiles>

Fig. (1). Quinazoline derivatives having therapeutical importance. 


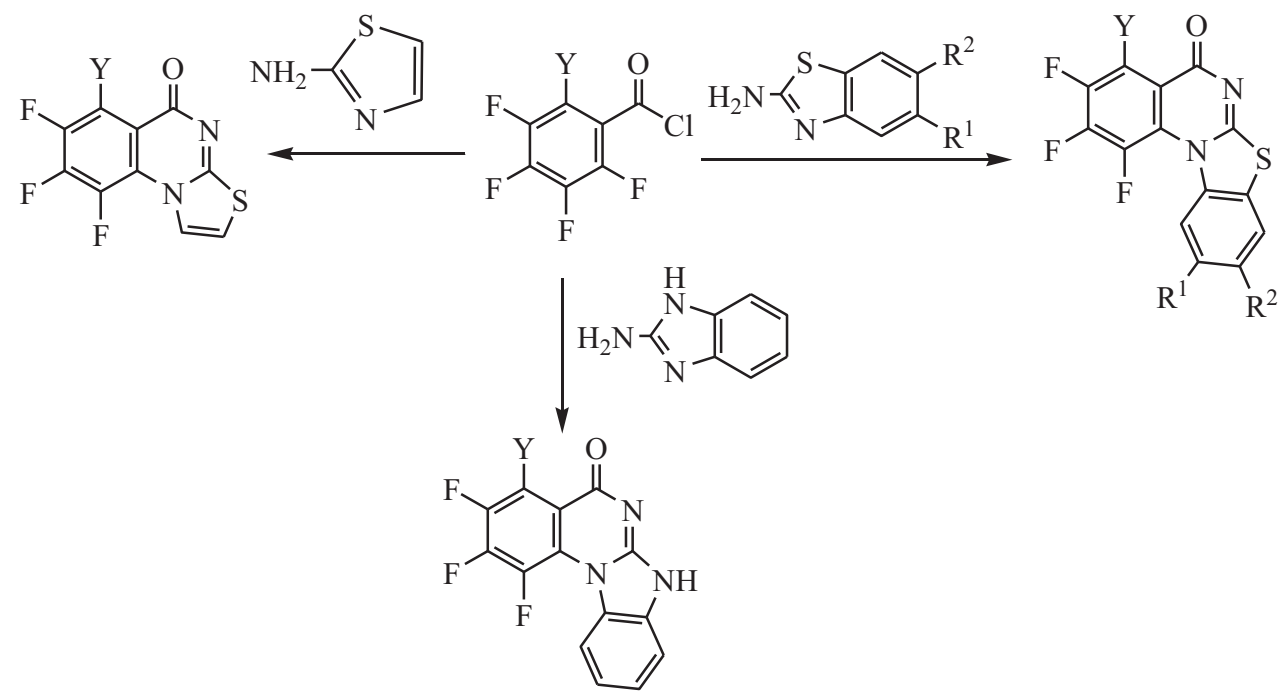

Scheme (1). Systemetic route of synthesis of annulated fluoroquinazolines.

Quinazolines and their derivatives were employed as important ligands, especially for benzodiazepine and GABA receptors in the central nervous system [59] or as deoxyribonucleic acid DNA binders [60]. Quinazoline and their derivatives have also been used to increase lipid solubility [61]. Quinazoline derivatives have also been reported to exhibit antitubercular, antimalarial, antiviral, antimicrobial, antiinflammatory and diuretic activities [62 - 64].

Due to their extraordinary behavior as bio-active material, quinazolines are elegant targets in organic synthesis. Quinazolines and their derivatives have been used as potent intermediates, especially for the preparation of clinical pharmaceuticals, drug intermediates, alkaloids and other materials. Quinazolinic structures [65] have been synthesized by different synthetic processes like Niementowski's synthesis [66], Bischler's synthesis [67] and Riedel's synthesis [68 - 70]. Annulated fluroquinazolines were synthesized by the reaction of 2-aminobenzothiazole, 2-aminoimidazole and 2aminothiazole with poly-fluorobenzoyl chlorides in the presence of di-phenyl ether (Scheme-1) [71]. The annulated fluoroquinazolines have been reported to exhibit wide-ranging biological activities such as antibacterial, antiviral, antitumour, etc. $[72,73]$.

Conventional methods of synthesis suffer from many disadvantages of organic synthesis, i.e., low yield, multistep procedure, time-consuming process, etc. Therefore, in view of the generation of structurally diverse molecules with structural complexity and interesting bio-activities in the least count of synthetic steps, annulated quinazolines have been synthesized by multicomponent reactions [74].

Quinazolinones derivatives such as benzimidazoquinazolinones have been synthesized by a more convenient multicomponent reaction (MCR) of aromatic aldehydes with 2aminobenzimidazole and dimedone using reusable sulfonic acid functionalized nano-porous silica ( $\left.\mathrm{SBA}-\mathrm{Pr}-\mathrm{SO}_{3} \mathrm{H}\right)$ under solvent-free conditions as more eco-friendly and nano solid acid catalyst (Scheme-2) [75].

Mohammadi et al. [76] introduced an important way for the preparation of substituted quinazoline-(3'H)-diones involving cyclo-condensation of amines, isatins, isatoic anhydride, and green catalyst like $\mathrm{KAl}\left(\mathrm{SO}_{4}\right)_{2} \cdot 12 \mathrm{H}_{2} \mathrm{O}$ (alum), (Scheme-3).<smiles>Nc1nc2ccccc2[nH]1</smiles><smiles>CC1(C)CC(=O)CC(=O)C1</smiles>
$\underset{\text { solvent free }}{\stackrel{\text { SBA-Pr-SO }}{\longrightarrow} \mathrm{H}}$<smiles>CC1C2=C(CC(C)(C)CC2=O)Nc2nc3ccccc3n21</smiles>

Scheme (2). Schematic presentaion for the synthesis of substituted quinazolinones. 


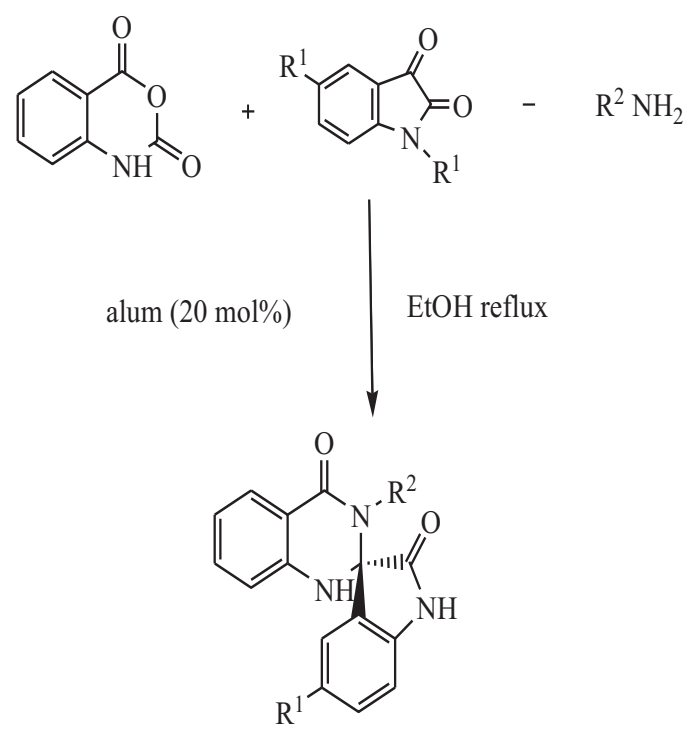

Scheme (3). Synthesis of novel substituted quinazoline-(3'H)-diones.

Zeng et al. [77] introduced a versatile and innovative path for the synthesis of fused quinazolines involving iodine catalyzed multicomponent reaction (MCR) of active methylene compounds with aromatic aldehydes (structurally diverse) and 5-aminotetrazole (Scheme-4).

Recently, Heravi et al. [78] synthesized triazolo/ benzimidazoloquinazolinones by an easy and effective threecomponent, a one-pot process which includes condensation of amine sources like 3-amino-1,2,4-triazole/2-aminobenzimi- dazole with different aldehydes and dimedone in the presence of sulfamic acid as green catalyst in acetonitrile under thermal conditions (Scheme-5).

With the same approach, convenient synthesis of benzothiazoloquinazolin-1-ones has also been reported [79] in which process involved the reaction of substituted benzenethiols with aromatic aldehydes and cyclohexanedione in refluxing DMF using anhydrous zinc chloride as catalyst (Scheme-6).

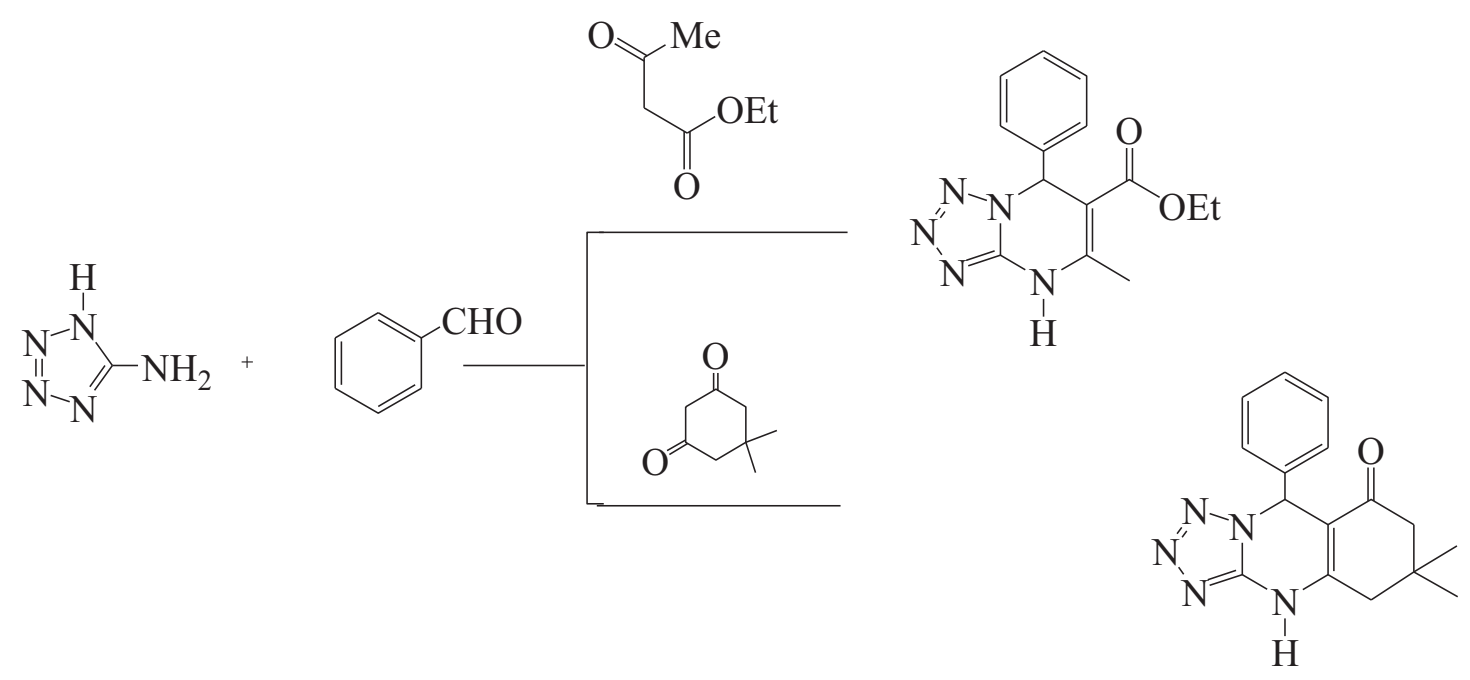

Scheme (4). Multicomponent synthesis of fused quinazolines. 


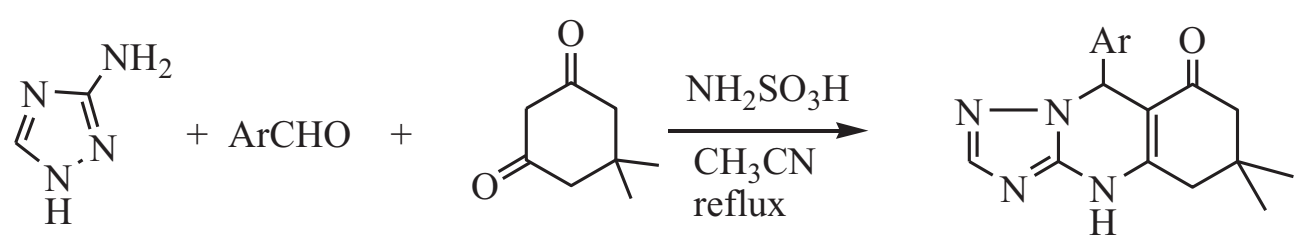<smiles>CC1(C)CC(=O)CC(C)(C)C1</smiles>

Scheme (5). Schematic presentation for the synthesis of 1,2,4-triazolo/ benzimidazolo-quinazolinones.<smiles>Nc1nc2ccccc2s1</smiles><smiles>O=C1CCCC(=O)C1</smiles>

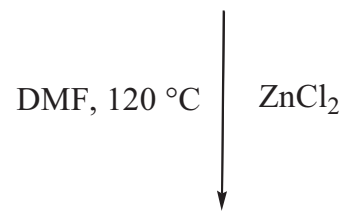<smiles>O=C1CCCC2=C1C(c1ccccc1)N1C(=N2)Sc2ccccc21</smiles>

Scheme (6). Schematic presentation for the synthesis of substituted-thiazolo-quinazolinones.

Gladkov et al. [80] recently synthesized triazoloquinazolin-8-ones by multicomponent reaction (MCR) of 4amino-1,2,3-triazoles with cyclic diketones (1,3) and aldehydes(aromatic) in refluxing DMF (Scheme-7).

1,2,3,4-Tetrahydroquinazolines [81] were synthesized by the use of two different methods, grinding and oil bath. Both the methods involved the reaction of 2-aminobenzylamine and benzaldehydes and observed approximately the same yield. But oil bath method is most effective with respect to the required time. The reaction was also performed with water as a solvent and required more time as compared to both methods used earlier (Scheme-8a).

Fu et al. developed an efficient method for the synthesis of pyrazolo[1,5-c] quinazolines via a one-pot two-step process involving readily available substituted 1-(2- halophenyl)-3alkylprop-2-yn-1-ones, hydrazine hydrochloride and amidine hydrochlorides using inexpensive $\mathrm{CuI}$ as a catalyst. The method affords a new strategy for the construction of diverse and useful poly $N$-heterocyclic compounds. (Scheme-8b) 
<smiles>[R]C=O</smiles><smiles>[R]C1([R])CC(=O)CC(=O)C1</smiles>

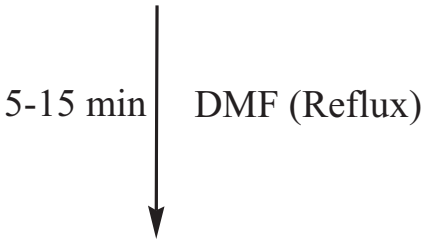<smiles>[R]c1nnn2c1NC1=C(C(=O)CC([R])([R])C1)C2[R]</smiles>

Scheme (7). Synthesis of highly substituted triazoloquinazolin-8-ones.

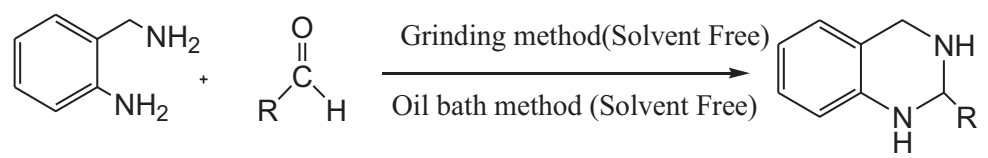

Scheme (8a). Solvent-free synthesis of substituted-quinazolines.<smiles>[R]C=CC(=O)c1ccc(Br)cc1[X]</smiles>

(1) $\mathrm{NH}_{2}-\mathrm{NH}_{2} \cdot \mathrm{HCl}, \mathrm{CS}_{2} \mathrm{CO}_{3}$ DMSO, $60^{\circ} \mathrm{C}, 12$ hours<smiles>[R3]C(=N)N</smiles><smiles>[R]c1cc2c3cc[c-]cc3nc([R3])n2n1</smiles>

Scheme (8b). Efficient method for the synthesis of pyrazolo[1,5-c]quinazolines.

The practice of conventional solvents, i.e., tetrahydrofuran, toluene, dioxane, benzene and dimethyl formamide, can limit the attractiveness of these synthetic methods. Organic solvents used in conventional methods are often considered harmful to human health and responsible for adverse effects on the environment components, i.e., biotic and abiotic. Therefore, subjected to high waste disposal costs and government restrictions because of environmental concerns, researchers focused to develop new methodology incorporating microwave irradiations for the synthesis of important annulated quinazolines. Functionalized quinazolines were synthesized by microwave influenced reaction of $O$-phenyl oximes with aldehydes. 2-aminoarylalkanone $O$-phenyl oximes were synthesized and then treated with an aldehyde in toluene under 
microwave heating to obtain functionalized dihydroquinazolines (Scheme-9) [82 - 84].

Substituted quinazoline-carbonitriles were synthesized by the multicomponent reaction of aldehydes, cycloketones, and cyanoamides, which act as both substrates and nucleophiles. Under microwave irradiation (M.W.), reaction was performed with ease by mixing four reactants and potassium carbonate in ethylene glycol (Scheme-10) [85].

2,4-Disubstituted1,2-dihydroquinazolines were also synthesized by multicomponent reaction (MCR) of aromatic aldehydes and 2-aminobenzophenone under M.W. conditions using urea as a source of ammonia. In this reaction, the corresponding quinazoline is also obtained as a minor product (Scheme-11) [86].

Quinolinoquinzolines and other fused heterocycles have also been synthesized by the microwave-assisted multicomponent reaction of enaminones, malonitrile and aldehydes. In this synthesis, the lactam ring is generated as a result of the reaction (Scheme-12) [87].

Kumar et al. introduced a one-pot, three-component sequential synthesis for the synthesis of benzothiazoloquinazolines, incorporating medicinally privileged heterosystems (Scheme-13a)

The literature survey reveals that bio-based solvents are suitable for the wide scope of organic reactions. These solvents hold considerable additional promise to reduce the environmental impact. Khandelwal et al. developed a convenient and environmentally benign diversity-oriented synthetic strategy to synthesize 2,3-dihydroquinazolin-4(1H) one derivatives using GAAS as a bio-based green solvent. The synthesis of 2,3-dihydroquinazolinones involved a multicomponent reaction of isatoic anhydride, substituted anilines and aromatic aldehydes in gluconic acid aqueous solution $(50 \%$, wt \%). (Scheme-13b) [88].

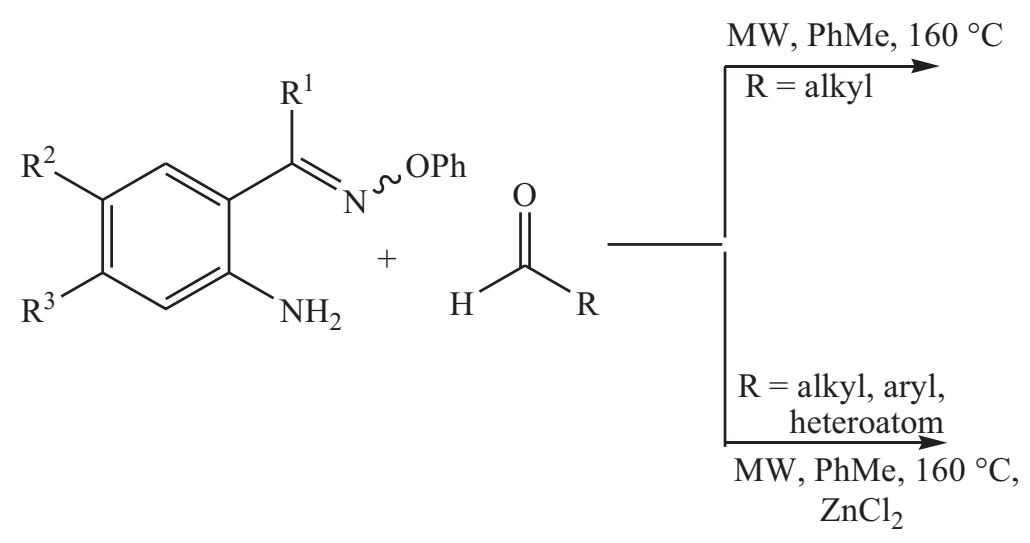<smiles>[R]C1=NC([R])Nc2cc([R])c([R])cc21</smiles>

Scheme (9). Microwave assited synthesis of functionalized dihydroquinazolines<smiles>O=C1CCCC1</smiles><smiles>O=CCBr</smiles><smiles>N#CCC(N)=O</smiles><smiles>CCCCCC(C)(C)C</smiles><smiles>N#CC1=C(N)[C@H]2C(=O)NC(=O)N[C@]23CCC[C@H]3[C@@H]1[Al]</smiles>

Scheme (10). Four-component synthesis of substituted quinazoline-carbonitriles. 
<smiles>[R]c1cccc(C(=O)c2ccccn2)c1N</smiles><smiles>O=Cc1ccccc1</smiles><smiles>NC(N)=O</smiles><smiles>[R]c1cccc2c1NC([Al])N=C2c1ccccn1</smiles><smiles>[R]c1cccc2c(-c3ccccn3)nc([Al])nc12</smiles>

Scheme (11). Three-component domino reaction leading dihydroquinazolines under M.W. conditions

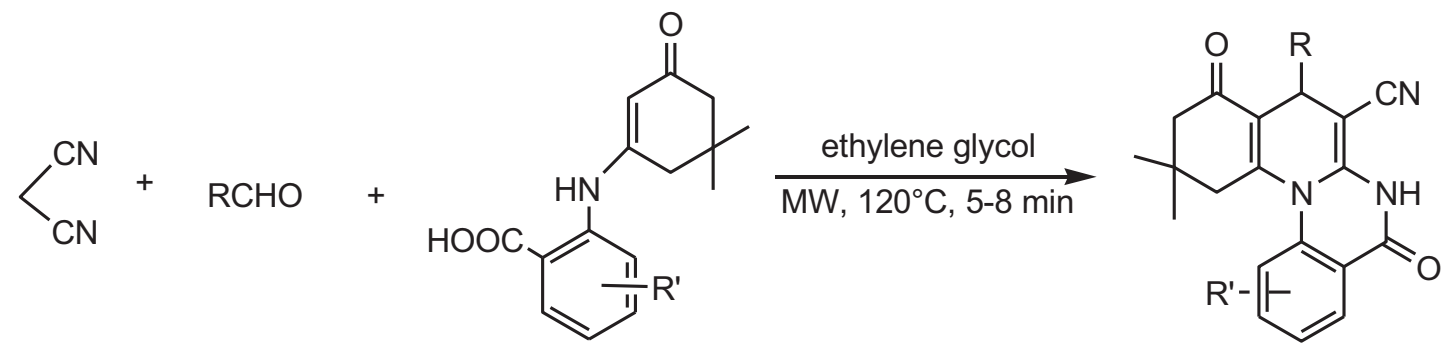

Scheme (12). Combinatorial synthesis of polysubstituent quinazoline derivatives under MW<smiles>[R]c1ccc2sc(N)nc2c1</smiles><smiles>[R]c1ccc2c(c1)SC1=NC3=C(CCc4ccccc43)C(c3cccs3)N12</smiles>

Scheme (13a). Triethylamine /ethanol catalytlized synthesis of Annulated benzothiazoloquinazolines.<smiles>Cc1ccc(Cl)cc1N</smiles>

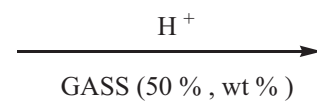<smiles>Cc1ccc(Cl)cc1N1C(=O)Nc2ccccc2C12Nc1ccccc1C2=O</smiles>

Scheme (13b). Synthesis of Structurally Diverse Spiroquinazolines. 
In the present time, the researchers have focused on the synthesis of quinazolines using ionic liquids (ILs) as ecofriendly solvents and catalysts. As compared to the conventional acid catalysts (homogeneous and heterogeneous), acidic ILs have demonstrated numerous advantages [89 - 96]. 2, 3-dihydroquinazolin-4(1H)-ones [97] were prepared by an efficient multicomponent reaction that involved the use of ionic liquids as a solvent-catalyst system. The synthetic method involved the reaction of 2 -aminobenzothiazole with isatoic anhydride and different aldehydes in the presence of ionic liquids (Scheme-14).

Quinazoline- 2,5-diones were prepared by the Biginelli reaction. The reaction involved the reaction between substituted dimedones, aldehydes and urea/thiourea using a combination of [bmim] Br and silica sulfuric acid as a catalyst (Scheme-15) [98].

4(3H)-Quinazolinones were synthesized by ionic liquid promoted synthetic method involving the reaction of 2-aminobenzamide with substituted aroyl chlorides in the presence ionic liquids like1-(4-sulfonic acid)butylpyridinium hydrogen sulfate $\left[\left(\mathrm{CH}_{2}\right)_{4} \mathrm{SO}_{3} \mathrm{HPY}\right]\left[\mathrm{HSO}_{4}\right]$, and 3-methyl-1-(4-sulfonic acid)butylimidazolium hydrogen sulfate $\left[\left(\mathrm{CH}_{2}\right)_{4} \mathrm{SO}_{3} \mathrm{HMIM}\right]$

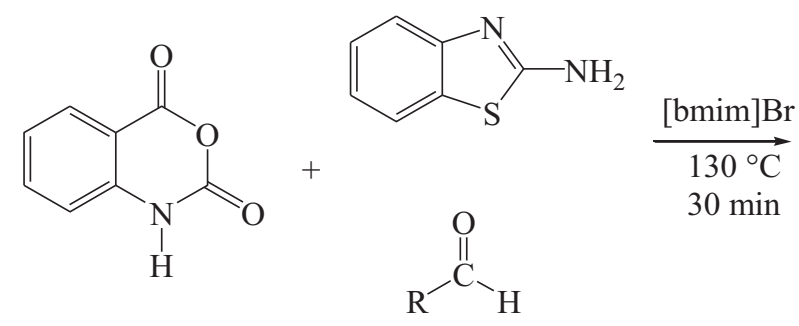

$\left[\mathrm{HSO}_{4}\right]$ as green and reusable catalysts with an excellent yield of the reaction product (Scheme-16) [99].

The reaction, reaction of anthranilic acid, trimethylorthoformate and primary amines in the presence of a catalytic amount of $\mathrm{Bi}(\mathrm{TFA})_{3}$ in ionic liquid butylpyridiniumtetrachloroferrate $[\mathrm{NBP}]\left[\mathrm{FeCl}_{4}\right]$ also provided quinazolinones (Scheme-17) [100].

Sharma et al. reported the synthesis of benzo thiazoloquinazolines- an ecofriendly, efficient synthetic method which involved three-component domino reaction of 2aminobenzothiazoles, a-tetralone, and furan-2-carbaldehyde/pmethoxybenzaldehyde using an $\mathrm{SO}_{3} \mathrm{H}$-functionalized halogenfree ionic liquid ([MIM $\left.\left.\left(\mathrm{CH}_{2}\right)_{4} \mathrm{SO}_{3} \mathrm{H}\right]\left[\mathrm{HSO}_{4}\right]\right)$ as a catalyst and solvent a(Scheme-18) [101].

Kumar et al. developed a new synthetic approach for the synthesis of 3-benzothiazolyl-2-styrylquinazolin-4(3H)-ones with excellent yields using ionic liquid as catalyst and reaction medium. The present method provided excellent results as compared to the results observed with the use of conventional solvents such as DMF, $\mathrm{CH} 3 \mathrm{CN}$, glacial acetic acid, and ethanol (Scheme-19) [102 - 104].<smiles>[R]C1Nc2ccccc2C(=O)N1c1nc2ccccc2s1</smiles>

Scheme (14). Schematic presentation for the symthesis of sustituted quinazolin-4(1H)-ones.<smiles>CC1(C)CC(=O)CC(=O)C1</smiles><smiles>[R]c1ccccc1C=O</smiles><smiles>[X]C(N)=[W]</smiles><smiles>[R]c1ccccc1C1NC([X])NC2=C1C(=O)CC(C)(C)C2</smiles>

Scheme (15). Preparation of Quinazoline- 2,5-diones through Biginelli reaction.<smiles>NC(=O)c1ccccc1N</smiles><smiles>O=C(Cl)[Te]</smiles>

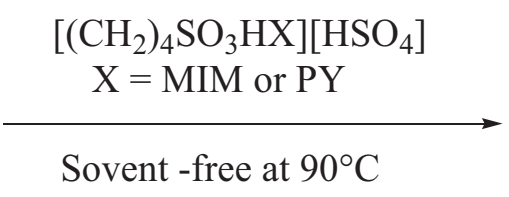<smiles>O=c1[nH]c([Al])nc2ccccc12</smiles>

Scheme (16). Quinazolinones synthesis using ionic liquids(ILs). 
<smiles>Nc1ccccc1C(=O)O</smiles><smiles>[R]CCN</smiles><smiles>COC(OC)OC</smiles>

$\mathrm{Bi}(\mathrm{Tfa})_{3},[\mathrm{NBP}]\left[\mathrm{FeCl}_{4}\right]$

$60{ }^{\circ} \mathrm{C}, 5-20 \mathrm{~min}$<smiles>[R]n1cnc2ccccc2c1=O</smiles>

Scheme (17). Synthesis of 4(3H)-Quinazolinones using ionic liquid.

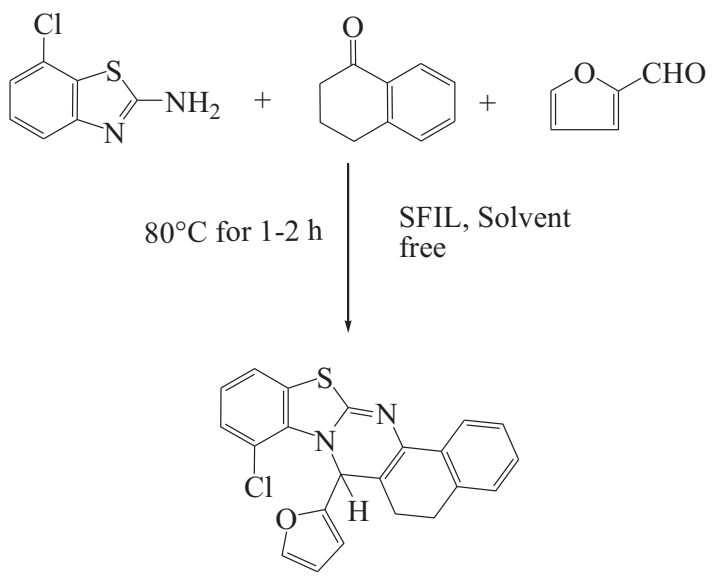

Scheme (18). Gree synthesis of benzothiazolo-quinazolines.

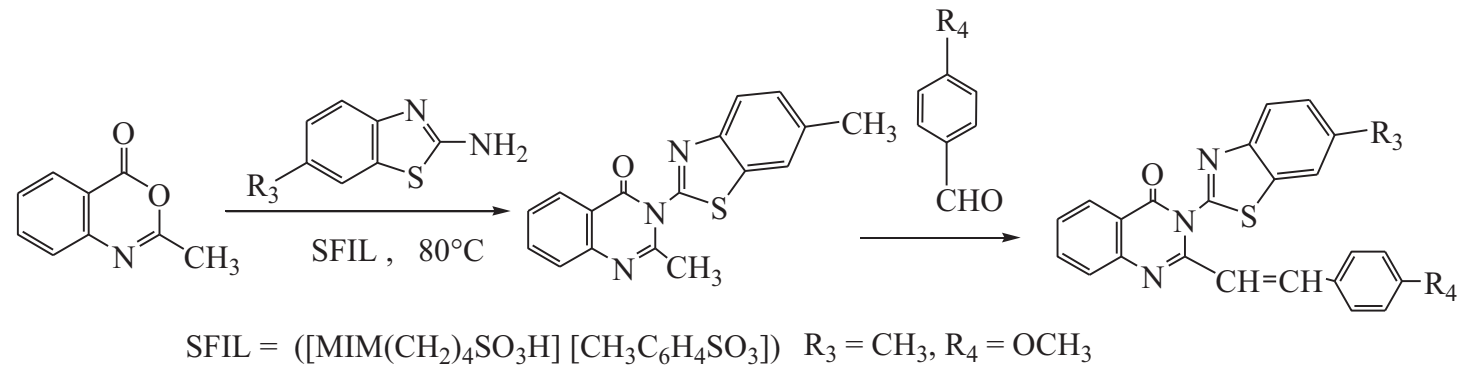

Scheme (19). Schematic presentation for the sunthesis of benzothiazolylstyrylquinazolinones

\section{CONCLUSION}

The literature survey reveals that very few publications have appeared in the literature related to the synthesis of quinazolines and their derivatives, which could not provide sufficient information to the researchers engaged in the synthesis of quinazolines and related drug-like small molecules incorporating quinazoline molecule. Most of the publications appeared in the literature are based on the synthesis of quinazolines using conventional methods. The present review article includes recent developments in the synthesis of quinazolines with the emphasis particularly on the environmentally sustainable multicomponent reactions (MCR) involving the use of Ionic Liquids (ILs) as a catalyst-solvent system.

\section{CONSENT FOR PUBLICATION}

Not applicable.

\section{FUNDING}

None

\section{CONFLICT OF INTEREST}

The authors declare no conflict of interest, financial or otherwise.

\section{ACKNOWLEDGEMENTS}

Declared none.

\section{REFERENCES}

[1] Khan, R.H.; Rastogi, R.C. Condensed heterocycles: synthesis and antifungal activity of. pi. deficientpyrimidines linked with.pi. richheterocycles. J. Agric. Food Chem., 1991, 39, 2300-2303. [http://dx.doi.org/10.1021/jf00012a042]

[2] aGrasso, S.; Micale, N. Monforte Anna-aria, Monforte, P.; Polimeni, S.; Zappala, M. Synthesis and antibacterial activity of thiazolo-, oxazolo-, and imidazolo[3,2-a][1,8]naphthyridinecarboxylic acids. 
Eur. J. Med. Chem., 2000, 35, 1115-1119.

[http://dx.doi.org/10.1016/S0223-5234(00)01195-8]

[PMID:

11248410] bGobinatha, M.; Subramanian, N.; Alagarsamy, V.; Nivedhithaa, S.; Solomon, V.R. Design and Synthesis of 1Substituted-4-(4-Nitrophenyl)- [1,2,4]triazolo[4,3-a]quinazolin-5(4H)ones as a New Class of Antihistaminic Agents. Russ. J. Bioorganic Chem., 2020, 46(3), 403-408.

[http://dx.doi.org/10.1134/S1068162020030085]

[3] aTestard, A.; Picot, L.; Lozach, O.; Blairvacq, M.; Meijer, L.; Murillo, L.; Piot, J-M.; Thiéry, V.; Besson, T. Synthesis and evaluation of the antiproliferative activity of novel thiazoloquinazolinone kinases inhibitors. J. Enzyme Inhib. Med. Chem., 2005, 20(6), 557-568. [http://dx.doi.org/10.1080/14756360500212399] [PMID: 16408791] bArya, K.; Tomar, R.; Rawat, D.S. Greener synthesis and photoantiproliferative activity of novel fluorinated benzothiazolo[2,3b]quinazolines. Med. Chem. Res., 2014, 23, 896-904. [http://dx.doi.org/10.1007/s00044-013-0689-y]

[4] Alexandre, F-R.; Berecibar, A.; Wrigglesworth, R.; Besson, T. Efficient synthesis of thiazoloquinazolinone derivatives. Tetrahedron Lett., 2003, 44, 4455-4458.

[http://dx.doi.org/10.1016/S0040-4039(03)01026-8]

[5] Quiroga, J.; Hernandez, P.; Insuastry, B.; Abonia, R.; Cobo, J.; Sanchez, A.; Nogueras, M.; Low, N.L. Control of the reaction between 2-aminobenzothiazoles and Mannich bases. Synthesis of pyrido[2,1b] [1,3]benzothiazoles versus [1,3]benzothiazolo[2,3-b]quinazolines. $J$. Chem. Soc. Perkin Trans., 2002, 1, 555-559.

[http://dx.doi.org/10.1039/b109676a]

[6] Rathore, B.S.; Kumar, M. Synthesis of 7-chloro-5-trifluoromethyl/7fluoro/7-trifluoromethyl-4H-1,4-benzothiazines as antimicrobial agents. Bioorg. Med. Chem., 2006, 14(16), 5678-5682. [http://dx.doi.org/10.1016/j.bmc.2006.04.009] [PMID: 16650998]

[7] Sharma, P.K. Antifungal, Antibacterial and Antioxidant activities of substituted Morpholinylbenzothiazine. Der Pharmacia Lettre, 2016, 8(11), 140-142.

[8] Sharma, P.K. Antibacterial, Antifungal and Antioxidant activities of substituted pyrazolylbenzothiazines. Der Pharmacia Lettre, 2016, $8(11), 79-82$.

[9] Sharma, P.K. Antifungal, Antibacterial and Antioxidant activities of substituted Morpholinylbenzothiazine. Der Pharmacia Lettre, 2016, 8(4), 86-90.

[10] Sharma, P.K. Antibacterial, Antifungal and Antioxidant activities of substituted 4H-1,4-benzothiazines. Der Pharma Chemica, 2016, 8(11), 156-159.

[11] Sharma, P.K. Antibacterial and Antifungal activity of Piperazinylbenzothiazine. Der Pharma Chemica, 2016, 8(5), 191-193.

[12] Sharma, P.K. A review: Different approach of bioactive pyrimidobenzothiazoles synthesis. Drug Invention Today, 2017, 9(3), $18-22$.

[13] Sharma, P.K. A review on antimicrobial activities of important thiazines based heterocycles. Drug Invention Today, 2017, 9(3), 23-25.

[14] Sharma, P.K.; Kumar, G. Synthesis, spectral, energetic and reactivity properties of phenothiazines: Experimental and computational approach. J. Chem. Pharm. Res., 2015, 7(11), 462-473.

[15] Sharma, P.K.; Kumar, M. Synthesis of bioactive substituted pyrazolylbenzothiazinones. Res. Chem. Intermed., 2015, 41(9), 6141-6148.

[http://dx.doi.org/10.1007/s11164-014-1727-1]

[16] Sharma, P.K.; Kumar, M. Synthesis and antimicrobial activity of structurally flexible heterocycles with the 1, 4-thiazine heterosystem. Res. Chem. Intermed., 2011, 37(8), 1103-1111.

[http://dx.doi.org/10.1007/s11164-011-0320-0]

[17] Sharma, P.K.; Kumar, M. Synthesis and antimicrobial activity of $2 \mathrm{H}$ pyrimido [2,1-b]benzothiazol-2-ones.Res. Chem. Intermed., 2010, 36(8), 985-993.

[http://dx.doi.org/10.1007/s11164-010-0211-9]

[18] Sharma, P.K.; Kumar, M. N-bridged heterocycles: regiospecific synthesis of 2-methyl-4H-pyrimido [2, 1-b] benzothiazol-4-ones. Res. Chem. Intermed., 2009, 35(1), 35-42.

[http://dx.doi.org/10.1007/s11164-008-0006-4]

[19] Sharma, P.K.; Kumar, M. Antimicrobial and antioxidant activities of substituted 4H-1, 4-benzothiazines. Med. Chem. Res., 2012, 21(8), 2072-2078.

[http://dx.doi.org/10.1007/s00044-011-9732-z]

[20] Sharma, P.K.; Kumar, M. One-pot, multicomponent sequential synthesis of benzothiazoloquinazolinones. Synth. Commun., 2010, 40(16), 2347-2352.

[http://dx.doi.org/10.1080/00397910903243807]
[21] Sharma, P.K.; Kumar, M. Synthesis of 2, 4-diaryl-2, 3-dihydro-1, 5benzothiazepines. Heterocycl. Commun., 2008, 14(3), 155-160.

[22] Sharma, P.K.; Sharma, K.; Kumar, M. Regioselective OnePot Synthesis of 5-Chloro-3-Methyl-8-Trifluoromethyl-4H-1, 4Benzothiazines. Heterocycl. Commun., 2009, 15(2), 127-134.

[23] Sharma, P.K. Synthesis of Starting Heterocycles: 2Aminobenzothiazoles, 2-Aminothiazoles and 2-Aminobenzenethiols Potential Precursors for Macroheterocycles. Macroheterocycles, 2018, 11(3), 316-321.

[http://dx.doi.org/10.6060/mhc171261s]

24] Sharma, P.K.; Kumari, M. Study of ethyl acetoacetate, 2 aminobenzenethiol and ceric ammoniumnitrate composition for biopharmaceutical applications. J. Phys. Conf. Ser., 2020, 1531012096 [http://dx.doi.org/10.1088/1742-6596/1531/1/012096]

[25] Sharma, P.K.; Saroha, S. Study of Heterocyclic Ring Systems: Biopharmaceutical Applications of Substituted 4H-1,4-Benzothiazine and Piperazine. J. Phys. Conf. Ser., 2020, 1531012094 [http://dx.doi.org/10.1088/1742-6596/1531/1/012094]

[26] Sharma, P.K. A review: Thiazines derivatives treated as potential antimicrobial agents. Asian J Pharm Clin Res, 2017, 10(1), 43-46. [http://dx.doi.org/10.22159/ajpcr.2017.v10i1.115467]

[27] Sharma, P.K. A review: Antimicrobial agents based on nitrogen and sulfur containing heterocycles. Asian J Pharm Clin Res, 2017, 10(2), $47-49$.

[http://dx.doi.org/10.22159/ajpcr.2017.v10i2.15673]

[28] aSharma, P.K. Andleeb, A.; Kumar, M. A Review: medicinally important nitrogen sulphur containing heterocycles. Open Med. Chem. J., 2020, 14, 49-64.

[http://dx.doi.org/10.2174/1874104502014010049] bSharma, P.K. Andleeb, A.; Kumar, M. Synthetic methods of medicinally important heterocycles-thiazine: A Review. Open Med. Chem. J., 2020, 14, $71-82$

[http://dx.doi.org/10.2174/1874104502014010071]

[29] Anastas, P.; Eghbali, N. Green chemistry: principles and practice. Chem. Soc. Rev., 2010, 39(1), 301-312.

[http://dx.doi.org/10.1039/B918763B] [PMID: 20023854]

[30] Nielsen, T.E.; Schreiber, S.L. Towards the optimal screening collection: a synthesis strategy. Angew. Chem. Int. Ed., 2008, 47(1), 48-56.

[http://dx.doi.org/10.1002/anie.200703073] [PMID: 18080276]

[31] Coquerel, Y.; Boddaert, T.; Presset, M.; Mailhol, D.; Rodriguez, J. Ideas in Chemistry and Molecular Sciences: Advances in Synthetic ChemistryPignataro, B. Wiley-VCH, Weinheim, Germany., 2010, 9, p. 187.

[32] Trost, B.M. On inventing reactions for atom economy. Acc. Chem. Res., 2002, 35(9), 695-705.

[http://dx.doi.org/10.1021/ar010068z] [PMID: 12234199]

[33] Wender, P.A.; Verma, V.A.; Paxton, T.J.; Pillow, T.H. Functionoriented synthesis, step economy, and drug design. Acc. Chem. Res., 2008, $41(1), 40-49$.

[http://dx.doi.org/10.1021/ar700155p] [PMID: 18159936]

[34] Hallett, J.P.; Welton, T. Room-temperature ionic liquids: solvents for synthesis and catalysis. 2. Chem. Rev., 2011, 111(5), 3508-3576. [http://dx.doi.org/10.1021/cr1003248] [PMID: 21469639]

[35] aMartins, M.A.P.; Frizzo, C.P.; Moreira, D.N.; Zanatta, N.; Bonacorso, H.G. Ionic liquids in heterocyclic synthesis. Chem. Rev., 2008, 108(6), 2015-2050.

[http://dx.doi.org/10.1021/cr078399y] [PMID: 18543878] bMishra, R.; Mishra, J.S.; Chaubey, S.A. Recent Advances on Triazolium Ionic Liquids: Synthesis and Applications. Curr. Org. Chem., 2019, 23, $1239-1255$

[http://dx.doi.org/10.2174/1385272823666190627114321]

[36] Wasserscheid, P.; Sesing, M.; Korth, W. Hydrogen sulfate and tetra kis (hydrogen sulfato) borate ionic liquids: synthesis and catalytic application in highly Brønsted-acidic systems for Friedel-Crafts alkylation. Green Chem., 4, 134 (2002). Green Chem., 2002, 4, 134-138.

[http://dx.doi.org/10.1039/b109845b]

[37] Zhao, D.B.; Wu, M.; Kou, Y.; Min, E.Z. Ionic liquids: applications in catalysis. Catal. Today, 2002, 74, 157-189.

[http://dx.doi.org/10.1016/S0920-5861(01)00541-7]

[38] Cocalia, V.A.; Visser, A.E.; Rogers, R.D.; Holbrey, J.D. Ionic Liquids in Synthesis; Wasserscheid, P.; Welton, T., Eds.; Wiley-VCH: Weinheim, Germany, 2008, 1, p. 89.

[39] aChakraborti, A.K.; Roy, S.R.J. On catalysis by ionic liquids. J. Am Chem. Soc., 2009, 131(20), 6902-6903. [http://dx.doi.org/10.1021/ja900076a] [PMID: 19413313] bMelo, L.R.; 
Silva, W.A. Ionic Liquid in Multicomponent Reactions: A Brief Review. Curr. Green Chem., 2016, 3, 120-132.

[http://dx.doi.org/10.2174/2213346103666160530143059]

[40] Maritinei-Viturro, C.M.; Dominguez, D. Synthesis of the antitumoural agent batracylin and related isoindolo[1,2- $b]$ quinazolin-12(10H)-ones. Tetrahedron Lett., 2007, 48, 1023-1026.

[http://dx.doi.org/10.1016/j.tetlet.2006.11.168]

[41] Selvam, P.; Girija, K.; Nagarajan, G.; De Clerco, E. Synthesis, Antibacterial And AntiHIV Activities Of 3-(5-Amino-6-(2-3Dichloro-Phenyl)-(1,2,4) Triazin-3-Y1)-6,8-Dibromo-2-Substituted -3H-Quinozolin-4-One. Indian J. Pharm. Sci., 2005, 67, 484-487.

[42] Kung, P.P.; Casper, M.D.; Cook, K.L.; Wilson-Lingardo, L.; Risen, L.M.; Vickers, T.A.; Ranken, R.; Blyn, L.B.; Wyatt, J.R.; Cook, P.D.; Ecker, D.J. Structure-activity relationships of novel 2-substituted quinazoline antibacterial agents. Med. Chem. (N.Y.), 1999, 42(22), $4705-4713$.

[http://dx.doi.org/10.1021/jm9903500] [PMID: 10579832]

[43] aMurugan, V.; Kulkarni, M.; Anand, R.M.; Kumar, E.P.; Suresh, B.; Reddy, V.M. Synthesis of 2 [ Bis-(2-chloroethyl) amino $\}$ methyl]-6, 8-dinitro-1-(4-substituted phenyl)-1H quinazolin-4-one derivatives as possible antineoplastic agents. Asian J. Chem., 2006, 18, 900-906.bFaghih, Z.; Rahmannejadi, N.; Sabet, R.; Zomorodian, K.; Asad, M.; Khabnadideh, S. Synthesis of some novel dibromo-2arylquinazolinone derivatives as cytotoxic agents. Res. Pharm. Sci., 2019, 14(2), 115-121.

[http://dx.doi.org/10.4103/1735-5362.253358] [PMID: 31620187]

[44] Godfrey, AAA Chem. Abstr. PCT Int. Appl., WO 2005012260 A2., 2005.

[45] Alagarsamy, V.; Raja Solomon, V.; Dhanabal, K. Synthesis and pharmacological evaluation of some 3-phenyl-2-substituted-3Hquinazolin-4-one as analgesic, anti-inflammatory agents. Bioorg. Med. Chem., 2007, 15(1), 235-241.

[http://dx.doi.org/10.1016/j.bmc.2006.09.065] [PMID: 17079148]

[46] Rachid, Z.; Brahimi, F.; Qiu, Q.; Williams, C.; Hartley, J.M.; Hartley, J.A.; Jean-Claude, B.J. Novel nitrogen mustard-armed combimolecules for the selective targeting of epidermal growth factor receptor overexperessing solid tumors: discovery of an unusual structure-activity relationship. J. Med. Chem., 2007, 50(11), 2605-2608.

[http://dx.doi.org/10.1021/jm070144p] [PMID: 17472358]

[47] Hori, M.; Iemura, R.; Hara, H.; Ozaki, A.; Sukamoto, T.; Ohtaka, H. Novel 4-phenoxy-2-(1-piperazinyl)quinazolines as potent anticonvulsive and antihypoxic agents. Chem. Pharm. Bull. (Tokyo), 1990, 38(3), 681-687.

[http://dx.doi.org/10.1248/cpb.38.681] [PMID: 2347010]

[48] Alagarsamy, V.; Pathak, U.S. Synthesis and antihypertensive activity of novel 3-benzyl-2-substituted-3H-[1,2,4]triazolo[5,1-b]quinazolin-9ones. Bioorg. Med. Chem., 2007, 15(10), 3457-3462. [http://dx.doi.org/10.1016/j.bmc.2007.03.007] [PMID: 17391966]

[49] Nishikawa, Y.; Shindo, T.; Ishii, K.; Nakamura, H.; Kona, T.; Uno, H. Synthesis and structure activity relationships of N-[4-[4(diphenylmethyl)-1-piperazinyl] butyl]-3-(3-pyridyl) acrylamides. $J$. Med. Chem., 1989, 32, 583-593.

[http://dx.doi.org/10.1021/jm00123a012] [PMID: 2465410]

[50] Havera, H.J.; Vidrio, H. Derivatives of 1,3-disubstituted 2,4(1H,3H)quinazolinediones as possible peripheral vasodilators or antihypertensive agents. J. Med. Chem., 1979, 22(12), 1548-1550. [http://dx.doi.org/10.1021/jm00198a024] [PMID: 231656]

[51] Chao, Q.; Deng, L.; Shih, H.; Leoni, L.M.; Genini, D.; Carson, D.A.; Cottam, H.B. Substituted isoquinolines and quinazolines as potential antiinflammatory agents. Synthesis and biological evaluation of inhibitors of tumor necrosis factor $\alpha . J$. Med. Chem., 1999, 42(19), 3860-3873.

[http://dx.doi.org/10.1021/jm9805900] [PMID: 10508435]

[52] Glaser, T.; Traber, J. TVX 2706--a new phosphodiesterase inhibitor with antiinflammatory action. Biochemical characterization. Agents Actions, 1984, 15(3-4), 341-348.

[http://dx.doi.org/10.1007/BF01972369] [PMID: 6098174]

[53] Liverton, N.J.; Armstrong, D.J.; Claremon, D.A.; Remy, D.C.; Baldwin, J.J.; Lynch, R.J.; Zhang, G.; Gould, R.J. Nonpeptide glycoprotein IIb/IIIa inhibitors: substituted quinazolinediones and quinazolinones as potent fibrinogen receptor antagonists. Bioorg. Med. Chem. Lett., 1998, 8(5), 483-486.

[http://dx.doi.org/10.1016/S0960-894X(98)00047-X] [PMID: 9871603]

[54] Vladimir, B.; David, C. Boyles, Timothy T. Curran, DainiusMacikenas, Roger V.; Parlett, I.V.; Derek Vrieze. The preparation of two, preclinical amino-quinazolinediones as antibacterial agents. Org. Process Res. Dev., 2007, 11(3), 441-449. [http://dx.doi.org/10.1021/op7000639]

[55] Alanine, A.; Gobbi, L.C.; Kolczewski, S.; Luebbers, T.; Peters, J-U.; Steward, L.U.S. Patent US 2006293350 A1, 2006, Chem. Abstr., 2006, 146, 100721.

[56] Chaturvedula, P.V.; Chen, L.; Civiello, R.; Degnan, A.P.; Dubowchik, G.M.; Han, X.; Jiang, X.J.; Macor, J.E.; Poindexter, G.S.; Tora, G.O.; Luo, G. U.S. Patent US 2007149503 A1. Chem. Abstr, 2007, 147, 118256.

[57] Letourneau, J.; Riviello, C.; Ho, K-K.; Chan, J-H.; Ohlmeyer, M.; Jokiel, P.; Neagu, I.; Morphy, J.R.; Napier, S.E.; Int, P.C.T. Appl.WO 2006095014 A1 2006. Chem. Abstr., 2006, 145315012

[58] Shen, L.L.; Mitscher, L.A.; Sharma, P.N.; O’Donnell, T.J.; Chu, D.W.T.; Cooper, C.S.; Rosen, T.; Pernet, A.G. Mechanism of inhibition of DNA gyrase by quinolone antibacterials: a cooperative drug--DNA binding model. Biochemistry: Biochem., 1989, 28(9), 3886-3894

[http://dx.doi.org/10.1021/bi00435a039] [PMID: 2546585]

[59] Colotta, V.; Catarzi, D.; Varano, F.; Lenzi, O.; Filacchioni, G.; Costagli, C.; Galli, A.; Ghelardini, C.; Galeotti, N.; Gratteri, P.; Sgrignani, J.; Deflorian, F.; Moro, S. Structural investigation of the 7chloro-3-hydroxy-1H-quinazoline-2,4-dione scaffold to obtain AMPA and kainate receptor selective antagonists. Synthesis, pharmacological, and molecular modeling studies. J. Med. Chem., 2006, 49(20), 6015-6026.

[http://dx.doi.org/10.1021/jm0604880] [PMID: 17004715]

[60] Malecki, N.; Carato, P.; Rigo, B.; Goossens, J.F.; Houssin, R.; Bailly, C.; Hénichart, J.P. Synthesis of condensed quinolines and quinazolines as DNA ligands. Bioorg. Med. Chem., 2004, 12(3), 641-647. [http://dx.doi.org/10.1016/j.bmc.2003.10.014] [PMID: 14738975]

[61] Graffner-Nordberg, M.; Kolmodin, K.; Aqvist, J.; Queener, S.F.; Hallberg, A. Design, synthesis, and computational affinity prediction of ester soft drugs as inhibitors of dihydrofolate reductase from Pneumocystis carinii. Eur. J. Pharm. Sci., 2004, 22(1), 43-54. [http://dx.doi.org/10.1016/j.ejps.2004.02.004] [PMID: 15113582]

[62] aChien, T-C.; Chen, C-S.; Yu, F-H.; Chern, J-W. Nucleosides XI. Synthesis and antiviral evaluation of $5^{\prime}$-alkylthio-5'-deoxy quinazolinone nucleoside derivatives as S-adenosyl-L-homocysteine analogs. Chem. Pharm. Bull. (Tokyo), 2004, 52(12), 1422-1426. [http://dx.doi.org/10.1248/cpb.52.1422] [PMID: 15577237] bBabu, R.R.; Naresh, K.; Ravi, A.; Reddy, B.M.; Babu, V.H. Synthesis of novel isoniazid incorporated styryl quinazolinones as anti-tubercular agents against INH sensitive and MDR M. tuberculosis strains. Med. Chem. Res., 2014, 23, 4414-4419. [http://dx.doi.org/10.1007/s00044-014-1020-2]

[63] Kung, P-P.; Casper, M.D.; Cook, K.L.; Wilson-Lingardo, L.; Risen, L.M.; Vickers, T.A.; Ranken, R.; Blyn, L.B.; Wyatt, J.R.; Cook, P.D.; Ecker, D.J. Structure-activity relationships of novel 2-substituted quinazoline antibacterial agents. J. Med. Chem., 1999, 42(22), 4705-4713.

[http://dx.doi.org/10.1021/jm9903500] [PMID: 10579832]

[64] Tinker, A.C.; Beaton, H.G.; Boughton-Smith, N.; Cook, T.R.; Cooper, S.L.; Fraser-Rae, L.; Hallam, K.; Hamley, P.; McInally, T.; Nicholls, D.J.; Pimm, A.D.; Wallace, A.V. 1,2-Dihydro-4-quinazolinamines: potent, highly selective inhibitors of inducible nitric oxide synthase which show antiinflammatory activity in vivo. J. Med. Chem., 2003 , 46(6), 913-916.

[http://dx.doi.org/10.1021/jm0255926] [PMID: 12620067]

[65] Michael, J.P. Quinoline, quinazoline and acridone alkaloids. Nat. Prod. Rep., 2005, 22(5), 627-646.

[http://dx.doi.org/10.1039/b413750g] [PMID: 16193160]

[66] Niementowski, S. Niementowski reaction: microwave induced and conventional synthesis of quinazolinone and 3-methyl-1H-5pyrazolone and their antimicrobial activity. J. Prakt. Chem., 1895, 51, 564-572.

[67] Bischler, A. Bischler's synthesis. Ber. Dtsch. Chem. Ges., 1891, 24 506-511.

[http://dx.doi.org/10.1002/cber.18910240194]

[68] Riedel, A. German Patent, 1905, 174941

[69] Rao, A.R.R.; Bahekar, R.H. Synthesis of benzimidazo[1,2-c ]quinazolines as possible bronchodilators. Indian J. Chem., 1999, 38, 434-439.

[70] Ozaki, K.; Yamada, Y.; Oine, T.; Ishizuka, T.; Iwasawa, Y. Studies on $4(1 \mathrm{H})$-quinazolinones. 5. Synthesis and antiinflammatory activity of 4(1H)-quinazolinone derivatives. J. Med. Chem., 1985, 28(5), 568-576. 
[http://dx.doi.org/10.1021/jm50001a006] [PMID: 3872940]

[71] Nosova, E.V.; Lipunova, G.N.; Laeva, A.A.; Charushin, V.N. Fluorocontaining Heterocycles: XIII. Fluoro-containing Derivatives of Thiazolo[3,2-a]-, Benzothiazolo[3,2-a]-, and Benzimidazo [3,2-a] quinazolinones. Russ. J. Org. Chem., 2005, 41(11), 1671-1677. [http://dx.doi.org/10.1007/s11178-006-0017-9]

[72] Chu, D.T.W.; Fernandes, P.B.; Pernet, A.G. Synthesis and biological activity of benzothiazolo[3,2-a]quinolone antibacterial agents. J. Med. Chem., 1986, 29(8), 1531-1534. [http://dx.doi.org/10.1021/jm00158a037] [PMID: 3090265]

[73] Kondo, H.; Taguchi, M.; Inoue, Y.; Sakamoto, F.; Tsukamoto, G. Synthesis and antibacterial activity of thiazolo-, oxazolo-, and imidazolo[3,2-a] $[1,8]$ naphthyridinecarboxylic acids. J. Med. Chem., 1990, 33(7), 2012-2015.

[http://dx.doi.org/10.1021/jm00169a033] [PMID: 2163456]

[74] Besson, T.; Guillard, J.; Rees, C.W. Multistep synthesis of thiazoloquinazolines under microwave irradiation in solution. Tetrahedron Lett., 2000, 41, 1027-1030. [http://dx.doi.org/10.1016/S0040-4039(99)02221-2]

[75] Ziarani, G.M.; Badiei, A.; Aslani, Z.; Lashgari, N. Application of sulfonic acid functionalizednanoporous silica (SBA-Pr-SO3H) in the green one-pot synthesis of triazoloquinazolinones and benzimidazoquinazolinones. Arab. J. Chem., 2011, 8, 54-61. [http://dx.doi.org/10.1016/j.arabjc.2011.06.020]

[76] Mohammadi, A.A.; Dabiri, M.; Qaraat, H. A regioselective threecomponent reaction for synthesis of novel $1^{\prime} \mathrm{H}$-spiro[isoindoline-1,2'quinazoline]-3,4'(3'H)-dione derivatives. Tetrahedron, 2009, 65(18), 3804-3808.

[http://dx.doi.org/10.1016/j.tet.2009.02.037]

[77] Zeng, L.Y.; Cai, C. Iodine catalyzed one-pot multicomponent synthesis of a library of compounds containing tetrazolo[1,5a]pyrimidine core. J. Comb. Chem., 2010, 12(1), 35-40. [http://dx.doi.org/10.1021/cc9000983] [PMID: 19950908]

[78] Heravi, M.M.; Derikvand, F.; Ranjbar, L. Sulfamic Acid-Catalyzed, Three-Component, One-Pot Synthesis of $[1,2,4]$ Triazolo/BenzimidazoloQuinazolinone Derivatives. Synth. Commun., 2010, 40(5), 677-685.

[http://dx.doi.org/10.1080/00397910903009489]

[79] Satish, A.D.; Sunil, U.T.; Swapnil, R.S.; Wamanrao, N.J.; Sudhakar, R.B.; Rajendra, P.P. Anhydrous Zinc Chloride: An efficient catalyst for one pot synthesis of 2,3,4,12-tetrahydro-benzo-[4,5]-thiazolo[2,3b]-quinazolin-1-ones. ARKIVOC, 2008, xvii, 241-247.

[80] Gladkov, E.S.; Sirko, S.N.; Shishkina, S.V.; Shishkin, O.V.; Knyazeva, I.V.; Desenko, S.M.; Chebanov, V.A. Efficient multicomponent synthesis of highly substituted $[1,2,3]$ triazolo[1,5a]pyrimidines. Monatsh. Chem., 2010, 141, 773-779.

[http://dx.doi.org/10.1007/s00706-010-0326-0]

[81] a Correa, W.H.; Papadopoulos, S.; Radnidge, P.; Roberts, B.A.; Scott, J.L. Direct, efficient, solvent-free synthesis of 2-aryl-1,2,3,4tetrahydroquinazolines. Green Chem., 2002, 4, 245-251. [http://dx.doi.org/10.1039/b202729c] b Fu, H.; Jin, Y.; Liu, H.; Jiang, Y.; Yang, X. Easy and efficient one-pot synthesis of pyrazolo[1,5c]quinazolines under mild copper-catalyzed conditions. RSC Advances, 2012, 2, 11061-11066.

[http://dx.doi.org/10.1039/c2ra21929h]

[82] Gedye, R.; Smith, F.; Westaway, K.; Ali, H.; Baldisera, L.; Laberge, L.; Rousell, J. The use of microwave ovens for rapid organic synthesis. Tetrahedron Lett., 1986, 27, 279-282.

[http://dx.doi.org/10.1016/S0040-4039(00)83996-9]

[83] Giguere, R.J.; Bray, T.L.; Duncan, S.M.; Majetich, G. Application of commercial microwave ovens to organic synthesis. Tetrahedron Lett., 1986, $27,4945-4948$

[http://dx.doi.org/10.1016/S0040-4039(00)85103-5]

[84] Portela-Cubillo, F.; Scott, J.S.; Walton, J.C. Microwave-promoted syntheses of quinazolines and dihydroquinazolines from 2aminoarylalkanone O-phenyl oximes. J. Org. Chem., 2009, 74(14), 4934-4942.

[http://dx.doi.org/10.1021/jo900629g] [PMID: 19449842]

[85] Jiang, B.; Tu, S-J.; Kaur, P.; Wever, W.; Li, G. Four-component domino reaction leading to multifunctionalized quinazolines. $J . \mathrm{Am}$. Chem. Soc., 2009, 131(33), 11660-11661.

[http://dx.doi.org/10.1021/ja904011s] [PMID: 19722590]

[86] Rupam, S.; Dipak, P. Microwave-promoted efficient synthesis of dihydroquinazolines. Green Chem., 2011, 13, 718-722.

[http://dx.doi.org/10.1039/c0gc00838a]

[87] Tu, S.; Li, C.; Li, G.; Cao, L.; Shao, Q.; Zhou, D.; Jiang, B.; Zhou, J.; Xia, M. Microwave-Assisted Combinatorial Synthesis of
PolysubstituentImidazo[1,2-a]quinoline, Pyrimido[1,2-a]quinoline and Quinolino[1,2-a]quinazoline Derivatives, 2007, 9(6), 1144-1148.

[88] a Kumar, M.; Sharma, K.; Sharma, D.K. Diversity oriented one-pot three-component sequential synthesis of annulated benzothiazoloquinazolines. Org. Med. Chem. Lett., 2012, 2(1), 10. [http://dx.doi.org/10.1186/2191-2858-2-10] [PMID: 22381142] b Paul, S.; Pradhan, K.; Das, A.R. Ethyl Lactate as a Green Solvent: A Promising Bio-compatible Media for Organic Synthesis. Curr. Green Chem., 2016, 3, 111-118.

[http://dx.doi.org/10.2174/2213346103666151203203139]

cKhandelwal, S.; Rajawat, A.; Tailor, Y.K.; Kumar, M. Efficient and Environmentally Benign Diversity Oriented Synthesis of 2, 3dihydroquinazolin-4(1H)-ones Using GAAS As a Bio-based Green Solvent. Curr. Green Chem., 2015, 2, 156-162.

[http://dx.doi.org/10.2174/2213346102666150121224434]

[89] Welton, T. Room-Temperature Ionic Liquids. Solvents for Synthesis and Catalysis. Chem. Rev., 1999, 99(8), 2071-2084.

[http://dx.doi.org/10.1021/cr980032t] [PMID: 11849019]

[90] Bourbigou, H.O.; Magna, L.; Morvan, D. Ionic liquids and catalysis: Recent progress from knowledge to applications. Appl. Catal. A., 2010, 373, 1-56.

[http://dx.doi.org/10.1016/j.apcata.2009.10.008]

[91] Merrigan, T.L.; Bates, E.D.; Dorman, S.C.; Davis, J.H. New fluorous ionic liquids function as surfactants in conventional room-temperature ionic liquids. Chem. Commun. (Camb.), 2000, 2051-2052.

[http://dx.doi.org/10.1039/b005418f]

[92] Davis, J.H.; Forrester, H.J. Thiazolium-ion based organic ionic liquids (OILs). Tetrahedron Lett., 1999, 40, 1621-1622.

[http://dx.doi.org/10.1016/S0040-4039(99)00025-8]

[93] Kim, Y.J.; Varma, R.S. Tetrahaloindate(III)-based ionic liquids in the coupling reaction of carbon dioxide and epoxides to generate cyclic carbonates: H-bonding and mechanistic studies. J. Org. Chem., 2005, 70(20), 7882-7891.

[http://dx.doi.org/10.1021/jo050699x] [PMID: 16277307]

[94] Cole, A.C.; Jensen, J.L.; Ntai, I.; Tran, K.L.; Weaver, K.J.; Forbes, D.C.; Davis, J.H., Jr; Davis, J.H. Novel Brønsted acidic ionic liquids and their use as dual solvent-catalysts. J. Am. Chem. Soc., 2002, 124(21), 5962-5963.

[http://dx.doi.org/10.1021/ja026290w] [PMID: 12022828]

[95] Huang, J.F.; Baker, G.A.; Luo, H.; Hong, K.; Li, Q.F.; Bjerrum, N.J.; Dai, S. Brønsted acidic room temperature ionic liquids derived from $N, N$-dimethylformamide and similar protophilic amides. Green Chem., 2006, 8, 599-602.

[http://dx.doi.org/10.1039/B604777G]

[96] Li, X.; Eli, W. A green approach for the synthesis of long chain aliphatic acid esters at room temperature. J. Mol. Catal. Chem., 2008, $279,159-164$.

[http://dx.doi.org/10.1016/j.molcata.2007.08.032]

[97] Shaabani, A.; Rahmati, A.; Rad, J.M. Synthesis of a novel class of 3(2'-benzothiazolyl)-2,3-dihydroquinazolin-4(1H)-ones under solventfree and catalyst-free conditions. J. Heterocycl. Chem., 2008, 45, 1629-1632.

[http://dx.doi.org/10.1002/jhet.5570450612]

[98] Shaabani, A.; Sarvary, A.; Rahmati, A.; Rezayan, A.H. Ionic Liquid/Silica sulfuric acid promoted fast synthesis of a Biginelli-like scaffold reaction. Lett. Org. Chem., 2007, 4, 68-71.

[http://dx.doi.org/10.2174/157017807780037531]

[99] Heravi, M.M.; Niloofar, T.H.; Bamoharram, F.F. Brønsted Acidic Ionic Liquids: New, Efficient, and Green Promoter System for the Synthesis of 4(3H)-Quinazolinones. Synth. Commun., 2011, 41, 707-714.

[http://dx.doi.org/10.1080/00397911003640108]

[100] Khosropour, A.R.; Mohammadpoor-Baltork, I.; Gohrbankhani, H. Bi $(\mathrm{TFA})_{3}-[\mathrm{nbp}] \mathrm{FeCl}_{4}$ : a new, efficient and reusable promoter system for the synthesis of $4(3 H)$-quinazolinone derivatives. Tetrahedron Lett., 2006, $47,3561-3564$.

[http://dx.doi.org/10.1016/j.tetlet.2006.03.079]

[101] Sharma, K.; Sharma, D.K.; Arya, A.K.; Kumar, M. An efficient and ecocompatible synthesis of annulated benzothiazoloquinazolines in $\mathrm{SO}_{3} \mathrm{H}$-functionalized ionic liquid. Res. Chem. Intermed., 2015, 41, 4133-4139.

[http://dx.doi.org/10.1007/s11164-013-1517-1]

[102] Kumar, M.; Sharma, K.; Sharma, D.K.; Arya, A.K. An efficient, ionic liquid mediated one-pot, three component sequential synthesis of 3benzothiazolyl-2-styrylquinazolin-4(3H)-ones. Tetrahedron Lett., 2013, 54, 878-882.

[http://dx.doi.org/10.1016/j.tetlet.2012.11.104] 
[103] Sharma, K.; Kumar, M. Synthesis and antimicrobial activity of 2,4diaryl-2,3-dihydrobenzo[b][1,4] thiazepines. Res. Chem. Intermed., 2013, 39(6), 2555-2564.

[http://dx.doi.org/10.1007/s11164-012-0782-8]

[104] Sharma, K.; Kumar, M. Use of $\mathrm{SO}_{3} \mathrm{H}$-functionalized halogen free ionic liquid ([MIM $\left.\left.\left(\mathrm{CH}_{2}\right)_{4} \mathrm{SO}_{3} \mathrm{H}\right]\left[\mathrm{HSO}_{4}\right]\right)$ as efficient promoter for the synthesis of structurally diverse spiroheterocycles. Tetrahedron Lett., 2012, 53(34), 4604-4608.

[http://dx.doi.org/10.1016/j.tetlet.2012.06.085]

\section{(C) 2020 Sharma et al.}

This is an open access article distributed under the terms of the Creative Commons Attribution 4.0 International Public License (CC-BY 4.0), a copy of which is available at: https://creativecommons.org/licenses/by/4.0/legalcode. This license permits unrestricted use, distribution, and reproduction in any medium, provided the original author and source are credited. 